\title{
Pengembangan Keterampilan Sosial Melalui Pembelajaran Puisi pada Siswa Sekolah Dasar Kelas V SD Muhammadiyah Kolombo Yogyakarta
}

\author{
Hilmiati $^{1}$
}

\begin{abstract}
Abstrak
Penelitian ini bertujuan untuk meningkatkan keterampilan sosial siswa kelas V SD Muhammadiyah Kolombo, Yogyakarta melalui peningkatan keterampilan membaca dan menulis puisi. Penelitian ini merupakan Penelitian Tindakan Kelas (PTK) yang terdiri atas delapan pertemuan dalam dua siklus dengan menggunakan model spiral menurut Kemmis dan Mc Taggart. Peneliti bertindak sebagai pengamat, sedangkan kolaborator utama, yaitu guru bahasa Indonesia yang mengajar kelas tersebut sebagai pelaksana tindakan. Kolaborator pembantu terdiri atas tiga orang pengamat. Teknik pengumpulan data yang digunakan adalah pengamatan, wawancara, dan dokumentasi: instrumen yang digunakan adalah tes sikap dan lembar pengamatan. Data keterampilan sosial dianalisis dengan teknik deskriftif kuantitatif dan data keterampilan membaca dan menulis puisi dianalisis dengan deskriptif kualitatif. Hasil penelitian menunjukkan bahwa: 1) peningkatan keterampilan sosial: a) rerata skor keterampilan sosial pada siklus pertama dengan rentang skor $1-40$ diperoleh 21,4 (cukup), pada siklus kedua meningkat menjadi 27,12 (baik); b) rerata skor tes sikap sebelum pelaksanaan tindakan dengan rentang skor $1-75$ diperoleh 42,9 (cukup), pada pascatindakan meningkat menjadi 54,9 (baik). 2) peningkatan keterampilan membaca pada siklus pertama dengan rentang 1-100 diperoleh 52,63\% (belum tuntas); pada siklus kedua meningkat menjadi $68,42 \%$ (tuntas) dan menulis puisi pada siklus pertama dengan rentang $1-100$ diperoleh $52,63 \%$ (belum tuntas); pada siklus kedua meningkat menjadi $73,68 \%$ (tuntas).
\end{abstract}

Kata kunci : keterampilan sosial, pembelajaran, puisi, kelas $V$, SD Muhammadiyah Kolombo Yogyakarta

\section{Pendahuluan}

Peraturan Menteri Pendidikan Nasional nomor 23 tahun 2006 menerangkan bahwa pendidikan dasar bertujuan meletakkan dasar kecerdasan, pengetahuan, kepribadian, akhlak mulia, serta keterampilan untuk hidup mandiri dan mengikuti pendidikan lebih lanjut. Berangkat dari peraturan

\footnotetext{
${ }^{1}$ Dosen pada IAIN Mataram
} 
pemerintah tersebut, penelitian ini diarahkan pada peningkatan keterampilan sosial anak. Sebagaimana diketahui bahwa pada kalangan siswa sekolah dasar memiliki masalah pribadi dan sosial. Oleh karena itu, setiap individu dituntut untuk menguasai keterampilan-keterampilan sosial dan kemampuan penyesuaian diri terhadap lingkungan sekitarnya.

Pendekatan pendidikan karakter pada penelitian formal di Indonesia kebanyakan masih bersifat tradisional, berupa pengajaran nilai-nilai moral dan pemberian teladan secara kurang memadai. Pengetahuan tentang nilai-nilai moral diajarkan secara langsung melalui mata pelajaran atau mata kuliah pendidikan Agama dan pendidikan Kewarganegaraan. Pendidikan karakter cenderung indroktinatif sehingga pengamalan nilai-nilai yang dipelajari dalam kehidupan sehari-hari tidak terlaksana atau hanya terlaksana kalau dilakukan pengawasan secara ketat. Tindakan sukarela (vulantary action) sebagai ciri khas perilaku moral tidak muncul dalam diri kebanyakan anggota masyarakat. Itulah sebabnya diperlukan pengintegrasian pembinaan karakter dalam berbagai bidang studi dan pembelajaran bahasa sangat sesuai untuk pengintegrasian tersebut.

Keterampilan sosial sebagai output dari pendidikan karakter seharusnya diintegrasikan dalam semua kegiatan belajar, tidak hanya menjadi tanggung jawab guru dan dosen Pendidikan Agama dan Pendidikan Kewarganegaraan. Pendidikan bahasa merupakan wahana yang tepat untuk membina karakter. Hal ini disebabkan oleh pandangan baru bahwa belajar bahasa seharusnya bersifat fungsional, digunakan untuk mempelajari bidang-bidang yang lain, sebab yang lain ialah bahwa pembelajaran bahasa sangat sesuai dilaksanakan secara tematik. Dalam kaitannya dengan pendidikan karakter, tema-tema yang dipilih dapat berupa nilai-nilai yang akan dikembangkan untuk menghasilkan pribadipribadi yang memiliki pengetahuan tentang kebaikan, menyenangi kebaikan, dan memiliki kebiasaan berperilaku baik (Zuchdi, 2009:2). Pengembangan keterampilan sosial hanya diterapkan pada mata pelajaran Ilmu Pengetahuan Sosial, Ilmu Pendidikan Kewarganegaraan dan Pendidikan Agama. Sementara dalam mata pelajaran bahasa Indonesia masih sangat minim membahas pengembangan keterampilan sosial. Melalui penelitian ini, peneliti mencoba mengkaji pengembangan keterampilan sosial melalui pembelajaran puisi.

Melalui penelitian ini, peneliti akan mengintegrasikan keterampilan sosial sebagai output dari pendidikan karakter ke dalam pembelajaran bahasa Indonesia melalui empat keterampilan sastra dalam mengembangkan 
keterampilan sosial siswa sekolah dasar kelas V SD Muhammadiyah Kolombo Yogyakarta.

Penelitian ini menggunakan metode penelitian tindakan yang difokuskan pada situasi kelas dan biasa disebut dengan penelitian tindakan kelas (PTK) atau Classroom Action Research. Rancangan model penelitian tindakan kelas yang dipakai dalam penelitian ini adalah mengacu pada model spiral atau siklus menurut Kemmis dan Mc Taggart (1988:14). Penelitian ini dilakukan dalam bentuk siklus, masing-masing siklus terdiri atas beberapa komponen, yaitu tahap persiapan, perencanaan, pelaksanaan tindakan, observasi, refleksi, evaluasi, dan kesimpulan hasil. Prosedur penelitian diilustrasikan dalam bentuk siklus pada gambar di bawah ini.

\section{Hasil dan Pembahasan}

\subsection{Keterampilan Sosial}

Keterampilan sosial siswa yang diamati mencakup kerjasama, menunjukkan tanggung jawab sosial dalam kelompok, membudayakan sikap displin, mendengarkan, berbicara, membaca, menuliskan ide/gagasan, bekerjasama dengan teman kelompok. Keterampilan sosial siswa kelas V SD Muhammadiyah Kolombo Yogyakarta dikatakan belum maksimal. Hal ini tidak terlepas dari peranan guru dalam mengembangkan strategi pembelajaran.

Penelitian tindakan kelas ini dilakukan untuk meningkatkan perilaku keterampilan sosial siswa melalui pembelajaran puisi. Melalui penelitian ini, keterampilan sosial sebagai output dari pendidikan karakter diintegrasikan ke dalam pembelajaran bahasa Indonesia, khusunya sastra, yaitu puisi. Dari hasil wawancara, pengintegrasian pendidikan karakter belum dikembangkan melalui pembelajaran puisi.

Berdasarkan hasil pengamatan yang telah diuraikan sebelumnya, keterampilan sosial siswa melalui pembelajaran puisi mengalami peningkatan. Hal tersebut akan dijelaskan sebagai berikut.

\subsubsection{Sikap sosial siswa}

Sebelum pelaksanaan tindakan, peneliti melihat sikap sosial siswa. Sikap sosial siswa diperoleh dari hasil angket yang diberikan siswa sebelum pelaksanaan tindakan. Angket sikap sosial siswa terdiri atas 15 butir pernyataan. Angket sikap sosial siswa tersebut diberikan sebelum pelaksanaan tindakan siklus I dan setelah pelaksanan tindakan siklus II. Hasil yang diperoleh dari 
angket pratindakan, skor rata-rata angket sikap sosial siswa 42,9. Rata-rata skor tersebut berada pada rentang skor $40-50$. Hal ini berarti bahwa skor rata-rata kelas angket sikap sosial siswa pratindakan berada pada kategori cukup. Sementara pada pascapelaksanaan tindakan siklus II, angket sikap sosial siswa 54,9. Rata-rata skor tersebut berada pada rentang skor 50-60. Hal ini berarti angket sikap sosial siswa berada pada kategori baik. Peningkatan tersebut dapat dilihat pada tabel 1 di bawah ini.

Tabel 1

Skor rata-rata perilaku sosial siswa pratindakan dan pascatindakan

\begin{tabular}{|c|c|c|}
\hline Siklus & Rata-rata hasil pengamatan & Kategori \\
\hline Siklus I & 21,4 & Cukup \\
\hline Siklus II & 27,12 & Baik \\
\hline
\end{tabular}

Peningkatan tersebut dapat dilihat pada gambar 1 di bawah ini.

\section{Gambar 1}

Grafik angket sikap sosial siswa

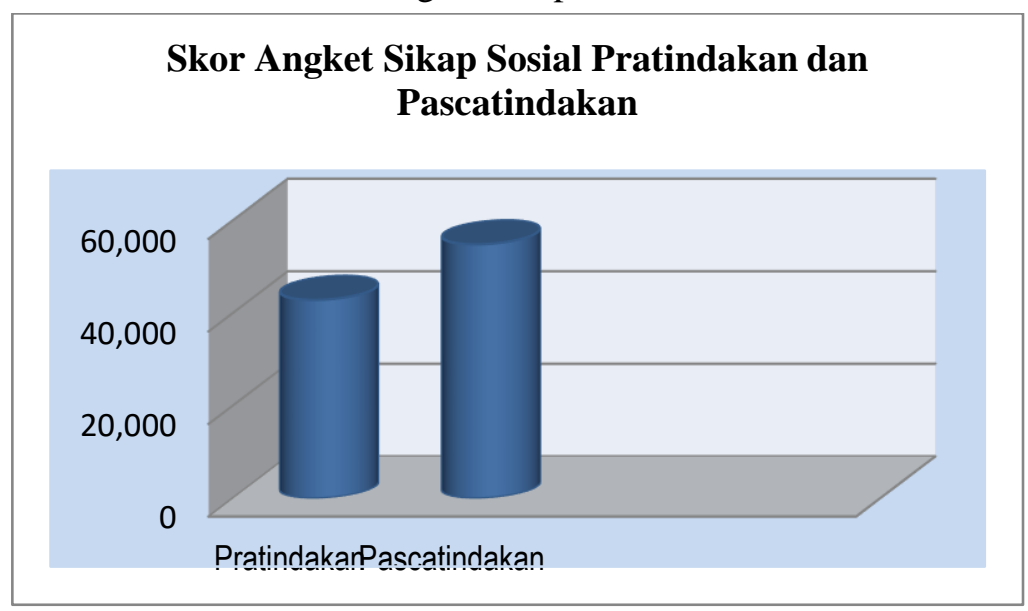

Gambar di atas menggambarkan bahwa melalui pembelajaran puisi, sikap sosial siswa mengalami peningkatan. Hasil angket pratindakan berada pada kategori cukup yang kemudian meningkat menjadi menjadi kategori baik pada hasil angket pascatindakan. Hal ini berarti bahwa pengembangan keterampilan sosial siswa melalui pembelajaran puisi sangat efektif.

\subsubsection{Perilaku keterampilan sosial}


Hasil pengamatan perilaku keterampilan sosial yang dilihat dari delapan aspek tersebut akan diuraikan sebagai berikut. Pada siklus I pertemuan pertama, rata-rata skor siswa 19,2. Rata-rata skor pertemuan 1 tersebut berada pada kategori kurang. Pada pertemuan kedua, rata-rata skor 20,5 yang berarti bahwa rata-rata skor berada pada kategori kurang. Pada pertemuan ketiga, rata-rata skor 22,3 yang menunjukkan bahwa rata-rata skor tersebut berada pada kategori cukup. Pertemuan keempat, rata-rata skor 23,5 yang menunjukkan bahwa jumlahtersebut berada pada kategori cukup. Berdasarkan jumlah rata-rata skor masing-masing pertemuan, rata-rata skor kelas pada siklus I 21,4 dengan kategori cukup. Jika dipersentasekan, jumlah tersebut berada pada level $53,44 \%$. Dengan berpatokan pada persentase standar acuan ketuntasan mengajar berdasarkan KTSP (60\%), ketuntasan mengajar siklus I belum memnuhi standar. Oleh karena itu, perlu dilanjutkan pada siklus berikutnya guna mencapai tujuan penelitian yang diharapkan.

Hasil pengamatan perilaku keterampilan sosial siswa pada siklus II, pertemuan pertama rata-rata skor 24,3. Rata-rata skor tersebut berada pada kategori cukup. Skor rata-rata pada pertemuan kedua, yakni 26,5. Rata-rata skor pertemuan kedua tersebut berada pada kategori cukup. Rata-rata skor siswa pada pertemuan ketiga, yakni 28,1. Rata-rata skor tersebut berada pada kategori baik. Rata-rata skor siswa pertemuan keempat, yakni 29,6 yang menunjukkan bahwa rata-rata skor tersebut berada pada kategori baik.

Berdasarkan hasil pengamatan dan uraian di atas, perilaku keterampilan sosial siswa pada siklus I rata-rata skor 21,4. Hal ini berarti bahwa perilaku keterampilan sosial siswa berada pada kategori cukup. Pada siklus II, perilaku keterampilan sosial siswa berada pada skor rata-rata 27,4. Hal ini berarti, ratarata skor pada siklus II berada pada kategori baik. Hasil pengamatan perilaku keterampilan sosial dalam kegiatan belajar menunjukkan peningkatan, yaitu dari kategori cukup menjadi kategori baik. Persentase kriteria ketuntasan mengajar pada siklus II meningkat dan memenuhi standar acuan kriteria ketuntasan sehingga sudah dikatakan tidak perlu melanjutkkan pada siklus berikutnya karena sudah memenuhi persentase ketuntasan yang diharapkan. 
34| Mabasan - Vol. 5, No. 1, Januari-Juni 2011

\subsection{Keterampilan membaca dan menulis puisi}

\subsubsection{Keterampilan membaca puisi}

Keterampilan membaca puisi aspek yang diamati ada tiga yaitu, vokal, intonasi, dan penghayatan. Kriteria yang digunakan di dalam mengamati keterampilan membaca puisi yaitu kurang, cukup, baik. Dalam KTSP 2007 dijelaskan bahwa persentase ketuntasan keterampilan membaca puisi adalah 60\%. Pada Siklus I kriteria cukup berada pada persentase 52,63\%. Berdasarkan persentase tersebut kriteria cukup belum dikatakan tuntas dan harus dilanjutkan pada siklus berikutnya yaitu siklus II. Sementara pada siklus II, keterampilan membaca pada kriteria cukup 68,42\%. Berdasarkan hasil tersebut, pelaksanaan siklus II bisa dikatakan telah mencapai tahap ketuntasan.

\subsubsection{Keterampilan menulis puisi}

Keterampilan menulis yang diamati empat aspek, yaitu pilihan kata, kedalaman makna, rima, dan tipografi. Pada siklus I, persentase keterampilan menulis puisi berada pada kriteria cukup, yakni 52,63\%. Persentase tersebut belum memenuhi kriteria dengan persentase ketuntasan. Pada siklus II kriteria cukup berada pada persentase $73,68 \%$. Hail ini menunjukkan bahwa siklus II telah memenuhi kriteria ketuntasan.

\section{Penutup}

\subsection{Simpulan}

Terjadi peningkatan dalam proses pembelajaran, sikap sosial, perilaku sosial, keterampilan membaca dan menulis puisi dari cukup ke baik.

\subsection{Saran}

Berdasarkan temuan pada penelitian tindakan kelas, maka diajukan saransaran sebagai berikut ini. Pertama, dalam pengembangan keterampilan sosial, siswa perlu memperhatikan delapan aspek untuk sekolah tingkat dasar, yaitu kerjasama dalam kelompok, tanggung jawab kelompok, disiplin, berbicara atau berdiskusi, menulis ide atau gagasan, dan kerjasama antar kelompok sehingga fokus dan dapat mencapai kompetensi secara maksimal.

Guru bahasa Indonesia (khususnya) dan guru mata pelajaran lainnya (umumnya) diharapkan memiliki kompetensi untuk mampu mengintegrasikan pendidikan karakter ke dalam mata pelajaran yang diajarkan dengan berbagai 
pendekatan dan strategi yang memungkinkan mampu diterima oleh peserta didik.

Dalam hal pengajaran sastra, khususnya sastra anak, guru mata pelajaran bahasa Indonesia seharusnya mampu menggunakan media yang ada dalam mengembangkan pendidikan karakter. Hai itu disebabkan karena sastra berperan sebagai usaha untuk membentuk dan mengembangakan kepribadian anak (character building). peran character building, khususnya keterampilan sosial merupakan modal atau pegangan hidup peserta didik di masyarakat dan dalam kehidupannya di masa yang akan datang.

\section{Daftar Pustaka}

Adiyanti, M.G. (1999). Skala Keterampilan Sosial (Surat Perjanjian Pelaksanaan Penelitian Nomor/j01.p/pl.06.05/98 tanggal 1 Juni 1998). Yogyakarta: Fakultas Psikologi UGM.

Agustian, Ary Ginanjar. (2005). ESQ: Emotional Spritual Quetion. Jakarta: Penerbit: ARGA.

Azhar Muhammad, L. (1993). Proses Belajar Mengajar (Pola CBSA). Surabaya: Usaha Nasional.

Azwar, Saefuddin. (2007). Sikap Manusia: Teori dan Pengukurannya. Yogyakarta: Pustaka Pelajar.

Broullitte, Liane. (2002). "Character School: Lesson in School Reform”. Dalam Harvard Education Review. Volume 95.

Cartledge, Cr and Milburn, J.F. (1992). Teaching Social Skill to Children: Innovative Approach. New York: Pergemon Press.

Darmiany. (2004). Pengembangan Paket Pelatihan Keterampilan Sosial Bagi Siswa Sekolah Menengah. Tersedia pada http://jurnal pendidikan humaniora sains.google. Diakses tanggal 3 April 2009.

Depdiknas (2003). Kurikulum 2004: Standar Kompetensi Kelas V Sekolah Dasar/Madrasah Ibtidaiyah. Jakarta: Puskur Dit PTK-SD.

Hamalik, Oemar. (2003). Kurikulum dan Pembelajaran. Jakarta: PT. Bumi Aksara. 
Hetherington, E., Mavis. Parke, dan Ross, D. (2003). Child Psichology: A Contemporary View Point ( $5^{\text {th }}$ ed). New York: McGraw-Hill.

Mardapi, Djemari. (2008). Teknik Penyusunan Instrumen Tes dan Nontes. Yogyakarta : Mitra Cendekia.

Mukminan. (1998). Belajar dan Pembelajaran. Yogyakarta: P4G.

Mutadin, Zainun (2002). Mengembangkan Keterampilan Sosial pada Remaja. Tersedia pada http://pembelajaran keetrampilan sosial. Google. Diakses tanggal 8 April 2009.

Nurgiyantoro, Burhan. (2005). Sastra Anak. Yogyakarta: Gadjah Mada University Press.

"Pedoman Penilaian Kelas," Kurikulum Tingkat Satuan Pendidikan. (2007). Jakarta: CV. Minajaya Abadi.

PPs UNY. (2008). Pedoman Tesis dan Desertasi Program Pascasarjana UNY. Yogyakarata: PPs UNY.

Pradopo., Rachmat Djoko . (2007). Pengkajian Puisi. Yogyakarta: Gadjah Mada University.

Prasetyo, Budi. (2007). Peningkatan Pembelajaran Puisi dengan Strategi Pikir Plus. Tersedia pada http://jurnal pendidikan inovatif/volume 2/pembelajaranpuisi.google. Diakses tanggal 4 Maret 2009.

Pusat Kurikulum Balitbang Depdiknas, Kurikulum Tingkat Satuan Pendidikan. , Pengembangan Model Pendidikan Kecakapan Hidup.

Rahman, Abdul. 1981. Kemampuan Apresiasi Sastra Murid SMA Jatim. Jakarta: Pusat Pembinaan dan Pengembangan Bahasa dan Sastra Departemen Pendidikan dan Kebudayaan.

Ramdhani, N. (1994). "Pelatihan Keterampilan Sosial pada Mahasiswa yang Sulit Bergaul”. Tesis Program Studi Pasca Sarjana UGM.

, (1995). "Pelatihan Keterampilan Sosial pada Mahasiswa yang Sulit Bergaul". Berkala Penelitian Pascasarjana Program Studi Pascasarjana UGM. 
Richardson, Rita Coombs, et.al. (2009). Character Education: Lessons for Teaching Social and Emotional Competence. Tersedia pada http//:www.ProQuest.Com/pqdweb. Diakses tanggal 6 Juni 2009.

Rofi'uddin, Ahmad., Zuchdi., dan Darmiyati. (2001). Pendidikan Bahasa dan Sastra Indonesia di Kelas Tinggi. Malang : Universitas Negeri Malang.

Sanjaya, Wina. (2007). Strategi Pembelajaran Berorientasi Standar Proses Pendidikan. Jakarta: Kencana.

Silberman, Mel. (1996). Active learning (101 Strategies to Teach Any Subject). Massachusetts: Temple University.

Slamet, St.Y. (2008). Dasar-dasar Pembelajaran Bahasa dan Sastra Indonesia di Sekolah Dasar. Jawa Tengah: UNS Press.

Sudaryanti. (2007). "Pengembangan Nilai-nilai Kejujuran, Keberanian dan Cinta Damai melalui Pembelajaran Berdasarkan Minat di TK Negeri 2 Yogyakarta”. Tesis Pascasarjana UNY.

Sujana, Nana. (1989). Dasar-dasar Proses Pelajar Mengajar. Bandung: Sinar Baru Algensindo.

Suryabrata, Sumadi. (1983). Proses Belajar Mengajar di Perguruan Tinggi. Yogyakarta: Andi Ofset.

Suryati, Atit. (27 Maret 2008). Implementasi Pendekatan Kontekstual untuk Meningkatkan Kemampuan Kreativitas Sastra. Tersedia pada http://educare.e-kipunla.net. Diakses tanggal 27 Maret 2009.

Suyatno. (2009). "Pembinaan Karakter melalui Pembelajaran Bahasa". Makalah disajikan dalam Seminar Nasional Inovasi Pembelajaran Bahasa dan Sastra dalam Rangka Pembinaan Karakter Bangsa di Era Globalisasi, di Universitas Negeri Yogyakarta.

Syamsul, B.T. (2005). "Persespi Interpersonal". Dalam Jurnal Pemikiran dan Psikologi, Volume 3 Nomor 1.

Syaodih, Erliany. (2009). Pengembangan Model Pembelajaran Kooperatif untuk Meningkatkan Keterampilan Sosial. Tersedia pada http://pengembangan keterampilan sosial ips. Google. Diakses tanggal 5 Maret 2009.

Taggart, Robin Mc. (1991). The Action Research (A Short Modern History). Deakin University.

Tompkins dan Hoskisson. (1984). Language Art ( $3^{r d}$ ed). Merril: Prentice Hall. 
38| Mabasan - Vol. 5, No. 1, Januari-Juni 2011

Wahidin, Dadan. (2009). Hakekat Pembelajaran Sastra. Tersedia pada http://hakekat sastra anak.google. Diakses tanggal 27 Maret 2009.

Woolfolk, A.E., dan McCune, L. (1984). Educational Psychology for Teacher. Engleword Chiff: Prentice Hill Inc.

Zuchdi, Darmiyati. (2008). Humanisasi Pendidikan. Yogyakarta: Bumi Aksara. , dkk. (2006). "Laporan Penelitian : Hibah Pascasarjana-HPTP (Hibah Pasca)" Universitas Negeri Yogyakarta.

.(2009). "Pembinaan Karakter melalui Pembelajaran Bahasa”. Makalah disajikan dalam Seminar Nasional Inovasi Pembelajaran Bahasa dan Sastra dalam Rangka Pembinaan Karakter Bangsa di Era Globalisasi, di Universitas Negeri Yogyakarta. 